\title{
Reconstruction of glacial lake outburst floods in northern Tien Shan: Implications for hazard assessment
}

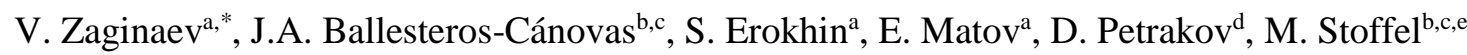 \\ (a) Institute of water problems and hydropower, National Academy of Science, Bishkek, Kyrgyzstan \\ (b) Dendrolab.ch, Institute of Geological Sciences, University of Berne, CH-3012 Berne, Switzerland
}

(c) Climatic Change and Climate Impacts, Institute for Environmental Sciences, University of Geneva, CH-1227 Carouge, Switzerland

(d) Faculty of Geography, Lomonosov Moscow State University, Moscow, Russia

(e) Department of Earth Sciences, University of Geneva, CH-1205 Geneva, Switzerland

* Corresponding author: zagivitjob@gmail.com (Vitalii Zaginaev)

\begin{abstract}
Glacier lake outburst floods (GLOFs) and related debris flows are among the most significant natural threats in the Tien Shan Mountains of Kyrgyzstan and have even caused the loss of life and damage to infrastructure in its capital Bishkek. An improved understanding of the occurrence of this process is essential so as to be able to design reliable disaster risk reduction strategies, even more so in view of ongoing climate change and scenarios of future evolutions. Here, we apply a dendrogeomorphic approach to reconstruct past debris-flow activity on the Aksay cone (Ala-Archa valley, Kyrgyz range), where outbursting glacier lakes and intense rainfalls have triggered huge debris flows over the past decades.
\end{abstract}

A total of 96 Picea abies (L.) Karst. trees growing on the cone and along the main channel have been selected based on the evidence of past debris-flow damage in their trunks; these trees were then sampled using increment borers. The dating of past events was based on the assessment of growth disturbances (GD) in the tree-ring records and included the detection of injuries, tangential rows of traumatic resin ducts, reaction wood, and abrupt growth changes. In total, 320 GD were identified in the tree-ring samples. In combination with aerial imagery and geomorphic recognition in the field, reactions in trees and their position on the cone have allowed reconstruction of the main spatial patterns of past events on the Aksay cone.

Our findings suggest that at least 27 debris flows have occurred on the site between 1877 and 2015 and point to the occurrence of at least 17 events that were not documented prior to this 
study. We also observe high process activity during the 1950s and 1960s, with major events on the cone in 1950,1966, and 1968, coinciding with phases of slight glacier advance. The spatial analyses of events also point to two different spatial patterns, suggesting that quite dissimilar magnitudes probably occurred during glacier lake outburst floods and rainfall-induced debrisflow events. The results presented here represent the longest, annually resolved GLOF series in the region, which in turn has key implications on risk assessment, not just in the Ala-Archa valley, but also in the entire Kyrgyz range (northern Tien Shan).

Keywords: debris flow; GLOF; tree rings; dendrogeomorphology; glacier; Aksay; Kyrgyz range; Kyrgyzstan

\section{Introduction}

Debris flows are rapid mass movements in which a combination of loose debris, rocks, organic matter, air, and water mobilize as a slurry which then flows downslope (Varnes, 1978; O'Connor et al., 2001). This natural process is considered one of the most common natural hazards in mountain environments and is responsible for significant damage to infrastructure and even loss of life (Fuchs et al., 2013; Borga et al., 2014). The causative factors of debris flows as well as their behavior, rheology, and geomorphic imprint have been described extensively in the literature (e.g., Costa, 1984; Rickenmann, 1999; Jakob and Hungr, 2005; Wu, 2015). Very huge debris flows can form as a result of glacial lake outburst floods (GLOFs; Richardson and Reynolds, 2000), which are typically formed from the breakage (e.g., seepage, piping) or the overflowing of moraine- or ice-dammed lakes (Worni et al., 2012, 2013a, 2014). These extreme events are able to shape debris cones and to produce intense changes in depositional forms (Breien et al., 2008) but also to affect environments located a long distance downstream of the source area of flows by disrupting networks and causing damage to populated valleys (Erochin and Cerny, 2009; Jansky et al., 2010; Schwanghart et al., 2016).

Over the past decades, numerous GLOFs have been documented in many mountain ranges worldwide. Examples of recent and large GLOF events are found in the Andes (Reynolds et al., 1998; Hegglin and Huggel, 2008), Central Asia (Aizen et al., 1997; Narama et al., 2006, 2010; Mergili and Schneider, 2011), the Himalayas (Richardson and Reynolds, 2000; Allen et al., 
2009; Xin et al., 2009; Worni et al., 2013b), the Rocky Mountains (Jakob and Bovis, 1996; Clague and Evans, 2000; Kershaw et al., 2005), the European Alps (Haeberli et al., 2001), and in the Mount Everest region (Cenderelli and Wohl, 2001, 2003). It is believed that the occurrence of these phenomena may increase over the next decades in many of the high mountain environments caused by (i) the formation of new unstable glacial and subglacial/englacial lakes as a result of glacier retreat and/or (ii) increasing slope destabilization in the cryosphere domain as a result of changes in the precipitation and temperature patterns (Aizen et al., 1996; Stoffel and Huggel, 2012; Stoffel et al., 2014). In the northern Tien Shan region, the IPCC projects a moderate increase in temperatures (IPCC, 2007), which is supposed to contribute or even to intensify current glacier retreat (Sorg et al., 2012, 2014). These changes may also cause significant modifications of the cryosphere (Sorg et al., 2015) and related instabilities at or around glacier termini and may thus impact on the actual formation or outburst of glacier lakes (Stoffel and Huggel, 2012). The widespread lack of long-term observations and more robust projections of climate change at the regional level have so far prevented more robust conclusions about possible changes in GLOF activity in the region.

Therefore, an improved understanding of past GLOF occurrences and their magnitude could indeed be a valuable baseline against which hypotheses about their relations with glacier dynamics could be tested and from which potential hazard zones at the level of fans and farther downstream in the valley could be drawn (Worni et al., 2014). So far, however, efforts have been focused primarily on the description of impacts of specific events causing disasters and not on hazard potential; and a longer-term perspective on the process has been clearly missing, such that the capacity of local authorities to perform sustainable hazard and risk assessments has been rather hampered.

Here, we combine an assessment of time series of aerial pictures, a detailed study of historical archives, field-based surveys, and tree-ring analyses to build the longest, annually resolved history of GLOF and debris-flow activity in northern Tien Shan. This paper therefore aims at improving our knowledge about the spatiotemporal dynamics of these processes on the Aksay fan, as a basis for future hazard assessments, at the site and within the larger study region. The well-preserved forest covering the Aksay fan allows studying impacted trees with dendrogeomorphic approaches (Stoffel and Corona, 2014). This approach has been used widely to analyze past debris flow events (see Bollschweiler and Stoffel, 2010a,b for a recent review) at local and regional scales (Bollschweiler and Stoffel, 2007; Mayer et al., 2010; Stoffel et al., 
2010; Procter et al., 2012; Šilhán et al., 2015) but has not been applied to understand GLOF activity in the past. In an attempt to distinguish GLOFs from debris flows, we hypothesize that the signs left and the spatial patterns would be different (Bollschweiler and Stoffel, 2007) and that the position of trees on the cone would help us in distinguishing dissimilar events with quite dissimilar magnitudes but operating in the same catchment. The hypothesis was first tested with available historical records.

\section{Study site}

The Aksay cone $\left(42^{\circ} 33^{\prime} \mathrm{N}\right.$; $\left.74^{\circ} 29^{\prime} \mathrm{E}\right)$ is the largest debris-flow fan in the Ala-Archa National Park (Fig. 1). It is located on the northern slope of the Kyrgyz range at only $35 \mathrm{~km}$ from Bishkek. The catchment size is ca. $28.3 \mathrm{~km}^{2}$, and ranges from 4895 to $2250 \mathrm{~m}$ asl. In the upper part of the catchment (above $3600 \mathrm{~m}$ a.s.1.), two valley glaciers can be found: (i) the Uchitel Glacier with an accumulation area on the western slopes of the Semenov Tianshanskiy (4,895 m a.s.1.) and Korona (4691 m a.s.1.) summits; and (ii) the Aksay Glacier, with an accumulation area located on the southwestern slopes of Korona and the western slope of Dvurogaya (4814 $\mathrm{m}$ a.s.1.) summits. The terminus of Uchitel Glacier is located at $3640 \mathrm{~m}$ a.s.l. and that of Aksay Glacier is at an elevation of $3330 \mathrm{~m}$ a.s.l. The lower parts of both glacier snouts are debris covered and seem to be stagnant. Roughly $1 \mathrm{~km}$ upslope of its terminus, Aksay Glacier exhibits an icefall with a slope of $52 \%$ and a vertical drop of up to $200 \mathrm{~m}$.

The debris-flow cone extends from 2200 to $2350 \mathrm{~m}$ a.s.1. and is covered by Picea abies in the areas where somewhat older sediments predominate and Betula in those sectors which have been affected by debris flows in the more recent past. The average slope on the fan is $16 \%$ for a cone area of 41.3 ha. The catchment has a Melton's ruggedness index of 0.5 and a Gravellius compactness index of 0.6. As a result of past debris-flow activity, several channels have been activated in the past and still are active today, whereas we also recognize features that have been more active in the past and can now be considered abandoned. On the hillslopes of the catchment and up to the treeline, located at ca. $2300 \mathrm{~m}$ a.s.l., vegetation is primarily formed by Picea abies trees.

Long-term hydrometeorological records exist at Baytik $\left(42^{\circ} 42.8^{\prime} \mathrm{N} ; 74^{\circ} 32.6^{\prime} \mathrm{E} ; 1300 \mathrm{~m}\right.$ a.s.1.), a station located at roughly $10 \mathrm{~km}$ downstream of Aksay valley. Annual records (covering the period 1916-2015) report mean precipitation totals of $517 \mathrm{~mm}$, ranging between $18.1 \mathrm{~mm}$ in January and $87.1 \mathrm{~mm}$ in May. Mean annual temperature is $6.5^{\circ} \mathrm{C}$, with mean maximum values in 
summer $\left(18.1^{\circ} \mathrm{C}\right)$ and lowest mean values in winter $\left(-4.8^{\circ} \mathrm{C}\right)$. On average, snow covers the debris-flow cone between September and April.

According to records of the Kyrgyz Hydrometeorogical Agency and the State Agency of Geology, past debris flows at Aksay cone have been triggered either by GLOF processes (and more precisely the outburst of englacial water pockets; Mavlyudov, 2005) or occurred as a result of intense rainfalls (Erochin et al., 2009). Also, existing records point to intense process activity on the cone during the second part of the twentieth century (Erochin and Dikih, 2003), but this clustering of events could also reflect the keen interest in and close monitoring of debris-flow processes by researchers of the USSR system. In addition, analyses of sediments and lichenometry suggest that large events have also been frequent at Aksay cone prior to the onset of systematic monitoring by USSR staff in the second half of the twentieth century and presumably even during the last centuries, including the Little Ice Age (Solomina et al., 1994).

(Figure 1)

\section{Material and methods}

\subsection{Geomorphic mapping and tree-ring sampling}

Geomorphic mapping was done through the interpretation of aerial pictures and satellite imagery interpretation (using pictures from 1960, 1971, 1978, and 2014) and field surveys, with the aim to characterize and distinguish passive from active debris channels as well as to map the main depositional areas and changes in forest cover. The most significant geomorphic features, namely debris-flow channels and depositional zones (i.e., lobes, levees) were manually digitized and incorporated into a geodatabase using ArcGIS ${ }^{\mathrm{TM}}$.

In a subsequent step, field recognition was carried out to identify the main landforms in the field and to locate trees bearing evidence of past events. Disturbed trees - and in particular wounded, tilted, decapitated, or buried trees (Stoffel and Bollschweiler, 2008) - were sampled if they were located on the cone and/or in exposed positions along the channels, lobes, and other depositional features. Sampling was realized following standard procedures in dendrogeomorphic research as described in Stoffel and Corona (2014) and consisted of the extraction of one or two increment cores per tree. Sampling was conducted according to the flow direction of events and at heights ranging between 20 and $100 \mathrm{~cm}$.

Sampling was restricted to the central and upper parts of the cone so as to limit the inclusion of noise in the reconstruction as a result of anthropogenic activities (i.e., tourist facilities) in its 
lower part. Samples from wounded trees were taken at the contact between the scar and intact wood so as to make sure that the entire tree-ring record was obtained (Schneuwly et al., 2009a,b; Ballesteros-Cánovas et al., 2010a,b; Stoffel and Corona, 2014). Sporadically, cross sections and wedges were also taken using a handsaw. Additionally, undisturbed trees were sampled on a hillslope located close to the cone so as to build the reference chronology representing normal, climate-driven growth in the area and for the purpose of cross-dating.

\subsection{Tree-ring analysis and spatiotemporal debris flow reconstruction}

Samples were prepared and measured following standard dendrochronological procedures (Stoffel and Corona, 2014). Tree rings were first counted and then measured with a precision of $0.01 \mathrm{~mm}$ using a digital LINTAB positioning table connected to a Leica stereomicroscope and the TSAPWin software (Rinntech, 2011). Tree rings from undisturbed trees were converted into width indices by standardizing raw data so as to detect characteristic common years with narrow or wide rings for visual and statistical cross-dating of the tree-ring series from disturbed trees (Stoffel and Bollschweiler, 2008). Growth disturbance (GD) induced by past debris-flow activity were then identified in the tree-rings records. Accordingly, following Stoffel and Corona (2014), GDs were attributed to three different reaction classes according to the evidence found in the tree-ring records: (i) strong reactions (i.e., injuries, intense tangential rows of traumatic resin ducts, or TRDs); (ii) medium reactions (i.e., callus tissues, compression wood, or intense abrupt growth changes); and (iii) weak reactions (i.e. moderate growth increases and/or growth suppressions). In those samples from Picea abies, the occurrence of TRDs was used as an indirect indicator of scars (Stoffel and Bollschweiler, 2008). The seasonality of events was assessed, whenever possible, based on historical records and on the position of wound borders and TRD on wedge samples (Stoffel et al., 2005, 2008). Owing to the lack of studies describing the response of trees to geomorphic disturances in this region, and in an attempt to minimize noise and to maximize signal, we have exclusively included intense TRDs in our assessment but disregarded intermediate and weak TRDs.

The definition of past debris flow event was based on the weighted index value $\left(W_{i t}\right)$ as defined by Kogelnig-Mayer et al. (2011) as well as the number of GD:

$W_{i t}=\left(\left(\sum_{i=1}^{n} T_{i} \times 7+\sum_{i=1}^{n} T_{s} \times 5+\sum_{i=1}^{n} T_{m} \times 3+\sum_{i=1}^{n} T_{w}\right)\right) \times \frac{\sum_{i=1}^{n} R_{t}}{\sum_{i=1}^{n} A_{t}}$ 
where the weighting factors of 7, 5, 3, and 1 are multiplied by the sum of trees containing GDs of decreasing intensity $\left(T_{i}>T_{s}>T_{m}>T_{w}\right)$, respectively. This is multiplied by the ratio of trees containing a GD in year $t\left(R_{t}\right)$ and the total number of trees alive in year $t\left(A_{t}\right)$.

This index considers the number, intensity, and typology of GDs within each tree-ring series and the total number of trees available for the reconstruction. The $W_{i t}$ is calculated for each year of the reconstruction and considers differences in the intensity of tree reactions to mechanic disturbance. Based on the existing bibliography, we defined the thresholds for the event identification according to the processes as well as the number of sampled trees (Stoffel et al., 2011; Schneuwly-Bollschweiler et al., 2013; Corona et al., 2014). We used the following thresholds to define debris flows: $W_{i t}>1.2$; for certain events; $1.2>W_{i t}>0.8$ for a possible event; $W_{i t}<0.8$ no event.

The position of all disturbed trees as well as the geomorphic features mapped on the images and in the field were displayed in ArcGIS ${ }^{\mathrm{TM}}$. We then performed a visual analysis of simultaneous reactions in trees to assess the possible clustering of disturbed trees or other spatial patterns pointing to damage induced by debris flows of varying magnitude. We therefore excluded years for which a limited number of trees were concentrated in very small areas (i.e., $<5 \mathrm{~m}$ ) or years for which reacting trees were highly dispersed and without defining a clear channel pattern (Lopez Sáez et al., 2011; Schneuwly-Bollschweiler and Stoffel, 2012; Stoffel et al., 2013). Finally, we interpret the spatial patterns of activity in current and past channels.

\section{Results}

\subsection{Geomorphic features and vegetation changes at Aksay cone}

The field survey and interpretation of aerial and satellite images revealed the existence of 11 well-formed debris-flow channels on the Aksay cone, as well as numerous accumulation forms in the form of levees and lobes. Figure 2 illustrates the geomorphic evolution and shifts in vegetation between the 1960 s and today and points to intense debris-flow activity over the last few decades. The southern part of the cone, which has been affected by debris flows throughout the period investigated, is characterized by deposits consisting mostly of boulders with sizes of up to 1-2 $\mathrm{m}$ and a clear lack of vegetation. The central part of the cone was seriously affected by debris flows between 1960 and 1971 and is characterized by the presence of huge boulders of up 
to 10-14 $\mathrm{m}$ in length, as well as by the existence of many affected trees behind the thick heaps of coarse sediment. In the northern part of the cone, some evidence exists for relatively recent channel activity, but the dense vegetation cover in this area points to more stable conditions here as compared to the central and southern parts of the cone. Nevertheless, we can observe several, yet old, disturbances of past debris-flow processes in trees as well as the presence of moderate to large boulders with block sizes ranging from 1 to $10 \mathrm{~m}$ on the present-day cone surface. The mapping and subsequent quantification of active channels and forest cover on the Aksay cone are shown in Fig. 3. The largest number of active channels was detected on the aerial image in 1971 (with seven active channels), when forest cover was much smaller than today (-33.6\%). By contrast, only three active channels (located in the southern sector) as well as a young forest stand in the central sector are identified on the satellite image of 2014 and confirmed during field inspection in 2015.

(Figure 2)

(Figure 3)

\subsection{Temporal reconstruction of past events at Aksay cone}

A total of 320 GDs were found in the 156 samples selected from 96 P. abies trees affected by past debris-flow activity. Among these GDs, $6 \%$ were in the form of injuries $(n=18), 25 \%$ were classified strong $(n=80)$, and $33 \%$ had medium $(n=105)$ and $36 \%$ had weak $(n=117)$ reactions. The oldest trees growing on the cone date back to A.D. 1850 and are located in the northern parts of the cone, whereas the youngest tree sampled within this study was located close to the currently active channels in the southern part of the cone; it attained sampling height in 1987.

Analysis of the temporal clustering of reactions and the spatial patterns of affected trees allowed reconstruction of 27 GLOF or rainfall-induced debris flows covering the last 140 years, thus pointing to the occurrence of 17 events that have not been known prior to this study. At the same time, the dendrogeomorphic study of debris flows on the Aksay cone has not only allowed confirmation of the events registered in USSR archives but also provided valuable insights into their lateral extent and reach. Table 1 and Fig. 5 provide specific details of these events and illustrate the temporal reconstruction of past debris flows on the Aksay cone. The oldest reconstructed event was dated to 1877 , whereas the most recent events were observed during 
fieldwork on 23 July 2015. Our reconstructions point to a phase of very intense debris-flow activity on the cone between 1960 and 1970 (0.54 events $\mathrm{y}^{-1}: 1960,1961,1965,1968,1969$, and $1970)$ and a sharp decrease in process activity after the 1970 s to the present day $\left(0.15\right.$ events $\mathrm{y}^{-1}$ : 1973, 1975, 1977, 1980, 1993, 1999, and 2015). Based on the available archival records from the USSR, nine of the dated debris flows were in fact caused by GLOFs (Table 2; i.e., 1960, 1961, 1965, 1966, 1968, 1969, 1970, 1975, and 1980). By contrast, only two events were released through the combined effect of intense rainfall and glacier thawing, namely in 1999 and 2015.

When comparing the weighted index $\left(W_{i t}\right)$ values obtained in different years (Fig. 8), we realize that the largest $W_{i t}$ indices are in fact obtained in those years for which GLOFs have been recorded in the USSR database. These are, by way of example, $1980\left(W_{i t}=22.3\right), 1960$ $\left(W_{i t}=12.8\right)$, or $1969\left(W_{i t}=10.6\right)$. We attribute these high values to (i) very intense, (ii) largemagnitude processes affecting (iii) substantial parts of Aksay cone and (iv) therefore leaving a larger number of evidence in trees. By contrast, the most recent events, known to be debris flows induced by rainfall and/or enhanced glacier melting, were characterized by much smaller $\mathrm{W}_{\text {it }}$ indices, as for instance in $1993\left(W_{i t}=1.4\right)$ or $1999\left(W_{i t}=2.1\right)$. By analogy, one can thus assume with fairly high confidence that the previously unknown debris flows dated to 1928 ( $\left.W_{i t}=15.6\right)$, $1936\left(W_{i t}=9.1\right)$, and $1950\left(W_{i t}=11.8\right)$ must have been triggered by outbursting lakes and not by torrential rainfalls.

In terms of the seasonal timing of debris flows, the intraseasonal position of injuries and TRDs within tree-ring records indicates that more than two-thirds of the events would have occurred in summer and that only $30 \%$ of the events were released in late spring (Table 1).

(Figure 4)

(Table 1)

\subsection{Reconstructed spatial patterns of debris flows}

The localization of trees showing simultaneous GD to a specific event have then allowed assessment of spatial patterns of debris-flow activity on the cone and for the 27 events identified between 1877 and 2015. Table 2 provides data on channel activity; results indicate quite clearly that channels 1,2, 3, and 6 have been affected most often during past events (with up to 13 events being recorded in a single channel). The most recent events in channels 3 and 8 were 
dated to 1999 and observed during fieldwork in 2015. By contrast, far less activity (only 3 events) has been observed in channel 9, with the last event on record in 1969. Analysis of the spatial distribution of GD in trees during specific events also allowed identification of two main flow or process patterns, which are described and illustrated in the following (Fig. 5):

(Figure 5)

(Table 2)

Pattern A: Large debris flows affecting the entire cone, likely induced by GLOFs

At least 15 events have affected the entire cone, namely in 1885, 1922, 1928, 1936, 1950, 1955, 1960, 1961, 1965, 1966, 1968, 1969, 1970, 1977, and 1980. In general terms, these events have been characterized by high-magnitude flow energies and large amounts of sediment being transported. Boulders during these events typically are $>1 \mathrm{~m}$ in diameter (Figs. 6A, B), and breakouts from the main channels (1, 2, and 4) usually occurred right at the cone apex. Based on historical records, at least the events in 1960, 1961, 1965, 1966, 1968, 1969, 1970, and 1980 were caused by outburst floods from lakes located on or next to Aksay glacier and should thus be considered GLOF events. Available historical records show that the deposition of large amounts of sediments has caused the formation of small lakes at the confluence of the Aksay torrent with the Ala-Archa River. This was particularly the case in 1968 when the outburst of an englacial water pocket and subsequent GLOF activated channels 1, 9, and 10, and debris-flow material covered the entire cone. In 1968, the foremost important impacts were recorded in the central part of the cone where tourist facilities have been constructed since.

The same pattern has been observed for the five following debris-flow events reconstructed in this study, namely 1922, 1928, 1936, 1950, and 1955 (Figs. 5B, C). During these events the spatial distribution of GD is mostly in channels 1, 9, 10, and 11; and damage in trees can be observed down to the confluence with the Ala-Archa River, pointing to a spread and extent similar to that observed during recent GLOF events.

(Figure 6)

Pattern B: Smaller debris flows being restricted to the southern parts of the cone

Pattern B describes somewhat smaller debris flows and can be described with the spatial distribution of trees affected by 12 past events, namely in 1877, 1916, 1918, 1924, 1934, 1941, 1943, 1973, 1975, 1993, 1999, and 2015. The two most recent events on record (1999 and 2015; Table 1) are also known from documentary sources, such that their triggers are known. In both cases, debris flows were released by a combination of intense rainfall and glacier melting. 
During pattern B events, debris flows exclusively affected channels 12 and 13, which are located in the southern part of the cone (Fig. 5D), but did not activate the channels in the central and northern parts of the cone. This difference in flow behavior can be explained by the smaller volumes of sediment and more limited availability of water during these flows which does not hence allow debris flows to favor avulsion processes at the apex of the cone. As a further consequence, the capacity of these events to produce temporal dams in the Ala-Archa River is also minimal, as most of the solid charge typically is being deposited on the cone itself. As pattern B events are restricted to the currently active channel (at least under present-day conditions), they also do not affect existing infrastructure on the Aksay cone.

\section{Discussion and conclusions}

In this paper, growth ring records from 96 Picea abies (L.) Karst. trees have allowed reconstruction of 27 debris-flow events covering the period A.D. 1877-2015. In addition, we were able to attribute possible triggers to the occurrence of debris flows and thus distinguish between (i) rather small, rainfall-induced debris flows and (ii) larger events occurring during glacier lake outburst floods (GLOFs).

Over the last few decades, glaciers of northern Tien Shan have shown a significant retreat and related mass losses as a result of climate warming, a process that has been enhanced by intensive melting because of significant summer warming (Aizen et al., 1997; Glazirin, 2010; Sorg et al., 2012; Bolch, 2015). This fact has led to the formation of a multitude of new and potentially unstable glacier lakes in the larger study area. As a consequence, local authorities are also confronted with potentially larger discharge volumes in case that the newly formed glacial lakes should eventually burst (Erochin et al., 2009). In this paper, we have put the recent developments into perspective by presenting a multicentennial debris-flow time-series for one of the more active sites in the Ala-Archa National Park near Bishkek. Besides the reconstruction of past debris flows, we have also analyzed hazards that might originate from the occurrence of GLOFs at the cone level and discussed possible linkages with glacier changes over the last decades.

The reconstruction of debris flows was based on standard dendrogeomorphic techniques (Bollschweiler and Stoffel, 2010a), with a focus on the analysis of injuries, strong TRD, reaction wood, and sudden growth reductions, as suggested by Stoffel and Corona (2014). The utility of these indicators has been proven for a large suite of hydrogeomorphic process reconstructions 
worldwide such as in the European Alps (Bollschweiler and Stoffel, 2010b; Procter et al., 2011, 2012), Carpathian Mountains (Šilhán, 2014; Ballesteros-Cánovas et al., 2015a,b), in the Central Spanish System (Ballesteros-Cánovas et al., 2010b, 2011a,b; Ruiz-Villanueva et al., 2010; Ballesteros-Cánovas et al., 2015c; Rodriguez-Morata et al., 2016), Patagonian Andes (Casteller et al., 2015), Japanese Alps (Trappmann et al., 2015), and in the Kazakh Tien Shan Mountains (Winchester et al., 2015) .

The position of affected trees was then used to investigate the spatial variability of reconstructed events (as in Bollschweiler et al., 2007) and to speculate about potential triggers of reconstructed events. Two different event patterns can be observed in the field, which allow hypothesizing that these differences also reflect the differing nature of geomorphic processes operating in the catchment. During pattern A, events affected the entire cone with large-sized deposits; whereas pattern B events exclusively affected the southern portions of the cone with smaller-grained debris flows. Based on the analysis of historical documents and the interpretation of aerial pictures, pattern A corresponds to past GLOF events, whereas imprints left by pattern B are induced by debris flows triggered by intense rainfall or snowmelt events. The distinction of triggers is also supported by the substantial differences observed in process magnitudes. During the events of 1968 and 1969, local authorities recorded peak discharge values of almost 900 and $800 \mathrm{~m}^{3} \mathrm{~s}^{-1}$, whereas discharge during the debris flows observed during fieldwork on 23 July 2015 was estimated to be between 90 and $150 \mathrm{~m}^{3} \mathrm{~s}^{-1}$ (Table 3). By using the spatial patterns and block size distributions of the 27 reconstructed events, we assume that 15 of them were indeed GLOFs originating from either the Uchitel or Aksay glaciers, whereas the remaining 12 debris flows (of much smaller size) would have been triggered by rainfall or snowmelt processes.

The temporal reliability of our reconstruction is well supported by existing records obtained from the State Agency of Geology and the Kyrgyz Hydrometeorological Agency, at least during Soviet time (1960-1980), for which data on events are very precise. We have therefore used the seasonality of damage in trees, mostly by means of the intra-position of TRD within growth rings (Stoffel, 2008, 2010) to confirm the reliability of our reconstruction and to further test the previously formulated assumptions. The (intraseasonal) dating of events did not only match with direct observations in 10 cases but furthermore allowed subseasonal reconstruction of 17 events that were not previously known. The fact that our study site was much more active than anticipated also confirms the conclusions of Solomina et al. (1994), who reported highly active process dynamics of the Aksay cone over the course of the Holocene, but also allows us to 
present unique data with unprecedented detail, not only for the region, which will greatly help understanding GLOF process dynamics and activity in northern Tien Shan and over the course of the last centuries.

In terms of system dynamics, our results also point to dissimilar event activity over the course of the last centuries. The temporal reconstruction of debris flows provides hints on three different activity phases and highlights an increase of process activity during the 1960s and 1970s. The reconstructed temporal frequency of events was only 0.25 event $\mathrm{y}^{-1}$ between 1916 and 1960, whereas more than one event in two years $\left(\sim 0.55\right.$ event $\left.\mathrm{y}^{-1}\right)$ was observed for the period 19601980, predominantly in the form of GLOF-induced debris-flows. During the most recent period (1980-2015), activity has become scarce with only $\sim 0.11$ events $\mathrm{y}^{-1}$, mostly in the form of rainfall or snowmelt-induced debris flows.

Comparable shifts in process activity and in the nature of triggers - with a clustering of GLOFinduced debris-flows in the 1960s-1980s — has also been reported for glacierized debris-flow catchments in Kazakhstan (Baimoldayev and Vinokhodov, 2007; Medeu, 2011). The reconstructed increase of event activity also matches well with the close-to-zero glacier mass balance of Golubin Glacier (reconstructed) in the Ala-Archa in the 1950s to the early 1970s (Aizen, 1988) or that of Tuyuksu Glacier (directly measured) in Kazakhstan (Dyurgerov and Mikhalenko, 1995).

The differences in triggers (and hence magnitudes) of debris flows at Aksay cone may thus well reflect predominating glaciological controls of glacier lake formation and/or outburst processes. It is possible that the state of glaciers in the Aksay catchment may have favored the blocking of englacial channels during this period of stagnant glacier mass balance, even more so as in the case of the Uchitel and Aksay glaciers where numerous crevasses are concentrated in the lower part of icefall (Figs. 7A, B). After 1960, Aksay Glacier has experienced rapid downwasting with an average reduction in mean surface elevation by almost $25 \mathrm{~m}$ and maxima in the lower parts of the snout of up to $60 \mathrm{~m}$ (Bolch, 2015). This significant thinning of the snout has not only caused terminus retreat and stagnation of ice in most areas of the snout below the icefall (Fig. 7C) but may also have impeded the formation of englacial channel blockage such that the accumulation of large meltwater masses has become insignificant and even hardly possible.

The hazard assessment on the cone highlights intense process activity, especially during summer. The highest probability for debris flows to occur thus coincides with the peak of the tourist 
inflow at Aksay during the summer season. Although old aerial pictures reveal that debris flows occurred throughout the period covered by images, pointing to frequent process activity in the central and northern parts of the cone, several tourist infrastructures have been constructed on the cone over the last decades. Even if the most recent debris flows of 1993, 1999, and 2015 were rather small in nature and restricted exclusively to the current main channel in the southern part of the cone, it is very likely that future GLOFs triggered by the outburst of englaciated lakes will avulse in the cone apex and reactivate currently abandoned channels in the central part of the cone. In addition to causing damage to infrastructure on the cone, these events may also result in the formation of a new temporary dam blocking Ala-Archa River and subsequently in catastrophic breakout floods farther downstream. The findings of this paper should thus be used for a critical reconsideration of the hazard zonation at the study site as well as for an implementation of disaster risk reduction strategies between the cone and the Kyrgyz capital Bishkek.

\section{Acknowledgements}

This study was funded by the Swiss National Science Foundation (SNF) in the framework of the DEFenCC (project $n^{\circ} 152301$; Future Debris Flows and lake outburst floods in Tien Shan: possible impacts of projected Climate Change) project. The authors would like to thank editorin-chief Richard A. Marston and the anonymous reviewers for their insightful and constructive comments.

\section{References}

Aizen, V. B., 1988. Golubin glacier mass balance reconstruction. Data Glaciol. Stud. 62, 119126.

Aizen, E.M., Aizen, V.B., Melack, J.M., 1996. Precipitation, melt and runoff in the northern Tien Shan. Journal of Hydrology, 186, 229-251. 
Aizen, V.B., Aizen, E.M., Melack, J.M., and Dozier, J. 1997. Climatic and Hydrologic Changes in the Tien Shan, Central Asia. Journal of Climate ,10 (6), 1393-1404.

Allen S.K., Schneider, D., Owens, I. F., 2009. First approaches towards modelling glacial hazards in the Mount Cook region of New Zealand's Southern Alps Nat. Hazards Earth Syst. Sci. 9, 481-499.

Baimoldayev, T., Vinokhodov, B., 2007. Kazaselezaschita, Almaty. (in Russian).

Ballesteros-Cánovas, J. A., Stoffel, M., Bollschweiler, M., Bodoque del Pozo, J. M., DíezHerrero, A., 2010a. Flash-flood impacts cause changes in wood anatomy of Alnus glutinosa, Fraxinus angustifolia and Quercus pyrenaica. Tree Physiology 30, 773-781.

Ballesteros-Cánovas, J. A., Stoffel, M., Bodoque del Pozo, J. M., Bollschweiler, M., Hitz, O. M., Diez-Herrero, A., 2010b. Changes in wood anatomy in tree rings of Pinus pinaster Ait. following wounding by flash floods. Tree-Ring Research 66, 93-103.

Ballesteros-Cánovas, J.A., Bodoque, J.M., Díez, A., Sanchez-Silva, M., Stoffel, M., 2011a. Calibration of floodplain roughness and estimation of palaeoflood discharge based on tree-ring evidence and hydraulic modelling. J. Hydrol. 403, 103-115.

Ballesteros-Cánovas, J.A., Eguibar, M., Bodoque, J.M., Díez, A., Stoffel, M., Gutiérrez, I., 2011b. Estimating flash flood discharge in an ungauged mountain catchment with 2D hydraulic models and dendrogeomorphic paleostage indicators. Hydrol. Process. 25, 970-979.

Ballesteros-Cánovas, J.A., Czajka, B., Janecka, K., Lempa, M., Kaczka, R.J., Stoffel, M., $2015 a$. Flash floods in the Tatra Mountain streams: frequency and triggers. Sci. Total Environ. 511, 639-648.

Ballesteros-Cánovas, J.A., Stoffel, M., Spyt, B., Janecka, K., Kaczka, R.J., Lempa, M., $2015 b$. Paleoflood discharge reconstruction in Tatra Mountain streams. Geomorphology http://dx.doi.org/10.1016/j.geomorph.2015.12.004 (in press).

Ballesteros-Cánovas, J.A., Rodríguez-Morata, C., Garófano-Gómez, V., Rubiales, J.M., Sánchez-Salguero, R., Stoffel, M., 2015c. Unravelling past flash flood activity in a forested mountain catchment of the Spanish Central System. J. Hydrol. 529 (2), 468-479.

Bolch T., 2015. Glacier area and mass changes since 1964 in the Ala Archa Valley, Kyrgyz AlaToo, northern Tien Shan. Ice and Snow 55(1), 28-39.

Bollschweiler, M., Stoffel, M., 2007. Debris flows on forested cones - reconstruction and comparison of frequencies in two catchments in Val Ferret, Switzerland. Natural Hazards and Earth System Sciences 7, 207-218. 
Bollschweiler, M., Stoffel, M., 2010a. Tree rings and debris flows - trends and challenges. Progress in Physical Geography 34, 625-645. doi:10.15356/2076-6734-2015-1-28-39.

Bollschweiler, M., Stoffel, M., 2010b. Changes and trends in debris-flow frequency since AD 1850: Results from the Swiss Alps. The Holocene 20: 907-916.

Bollschweiler, M., Stoffel, M., Ehmisch, M., Monbaron, M. 2007. Reconstructing spatiotemporal patterns of debris-flow activity using dendrogeomorphological methods. Geomorphology 87, 337-351.

Borga, M., Stoffel, M., Marchi, L., Marra, F., Jakob, M., 2014. Hydrogeomorphic response to extreme rainfall in headwater systems: flash floods and debris flows. Journal of Hydrology 518, 194-205.

Breien H., De Blasio, F.V., Elverhoi, A., Hoeg, K., 2008. Erosion and morphology of a debris flow caused by a glacial lake outburst flood, Western Norway. Landslides 5, 271-280. doi:10.1007/s10346-008-0118-3.

Casteller, A., Stoffel, M., Crespo, S., Villalba, R., Corona, C., Bianchi, E., 2015.

Dendrogeomorphic reconstruction of flash floods in the Patagonian Andes. Geomorphology 228, 116-123.

Cenderelli, D. A., Wohl, E., 2001. Peak discharge estimates of glaciallake outburst floods and "normal" climatic floods in the Mount Everest region, Nepal. Geomorphology, 40, 57-90.

Cenderelli, D. A., Wohl, E., 2003. Flow hydraulics and geomorphic effects of glacial-lake outburst floods in the Mount Everest region, Nepal. Earth Surf. Proc. Land., 28, 385-407.

Clague, J.J., Evans, S.G., 2000. A review of catastrophic drainage of moraine-dammed lakes in British Columbia. Quaternary Science Reviews 19, 1763-1783.

Corona, C., Lopez Sáez, J., Stoffel, M., 2014. Defining optimal sample size, sampling design and thresholds for dendrogeomorphic landslide sampling. Quat. Geochronol. 22, 72-84.

Costa, J. E., 1984. Physical geomorphology of debris flows, In: J. E. Costa and P. J. Fleischer (Eds.), Developments and Applications of Geomorphology, Springer, Berlin, Germany, pp. 268317.

Dyurgerov, M. B., Mikhalenko, V. N., 1995. Oledeneniye Tien Shanya (Glaciation of Tien Shan), VINITI, Moscow (in Russian). 
Erochin, S.A., Cerny M., 2009. Monitoring of outbursting lakes of Kyrgyzstan. Final Proc. Int. Conf. Mountain-hazards, Bishkek, Kyrgyzstan, pp. 30-34.

Erochin, S.A., Dikih A.N., 2003. Risk assessment of debris flow activities and flash floods on the territory of the Ala - Archa National Park. Bishkek, pp. Izvestiya NAS KR, 130-139. (in Russian)

Erochin, S.A., Mamatkanov, D.M., Tuzova, T.V., 2009. Monitoring of Kyrgyz lakes at risk of outburst floods. Final Proc. Int. Conf. Floods. Tbilisi, Georgia, pp. 130-147.

Fuchs, S., Keiler, M., Sokratov, S.A., Shnyparkov, A.L., 2013. Spatiotemporal dynamics: the need for an innovative approach in mountain hazard risk management. Natural Hazards 68 (3), $1217-1241$.

Glazirin, G.E., 2010. A century of investigations on outbursts of the ice-dammed lake Merzbacher (central Tien Shan). Austrian J. Earth Sci. 103, 171-179.

Haeberli, W., Kääb, A., Vonder Mühll, D., Teysseire, P., 2001. Prevention of outburst floods from periglacial lakes at Gruben Glacier, Valais, Swiss Alps. Journal of Glaciology 47, 111-122.

Hegglin, E., Huggel, C., 2008. An integrated assessment of vulnerability to glacial hazards - a case study in the Cordillera Blanca, Peru.Mountain Research and Development, 28, 299-309.

Jakob, M., Bovis, M.J., 1996. Morphometrical and geotechnical controls of debris flow activity, southern Coast Mountains, British Columbia, Canada. Zeitschrift für Geomorphologie Supplementband 104, 13-26.

Jakob, M., Hungr, O., 2005. Debris-flow Hazards and Related Phenomena. Springer, Berlin.

Jansky, B., Sobr, M., Engel, Z., 2010. Outburst flood hazard: case studies from the Tien-Shan mountains, Kyrgyzstan. Limnologica 40, 358-364.

Kershaw, J.A., Clague, J.J., Evans, S.G., 2005. Geomorphic and sedimentological signature of a two-phase outburst flood from moraine dammed Queen Bess Lake, British Columbia, Canada. Earth Surface Process and Landforms 30, 1-25.

Kogelnig-Mayer, B., Stoffel, M., Bollschweller, M., Hubl, J., Rudolf-Miklau, F., 2011. Possibilities and imitations of dendrogeomorphic time-series reconstructions on sites influenced by debris flows and frequent snow avalanche activity, Arct. Antarc. Alp. Res. 43 (3), 649-658. 
Lopez Sáez, J., Corona C., Stoffel M., Gotteland A., Berger F., Liébault F., 2011. Debris-flow activity in abandoned channels of the Manival torrent reconstructed with LiDAR and tree-ring data. Natural Hazards and Earth System Sciences 11, 1247-1257.

Mavlyudov, B., 2005. English-Russian dictionary on glacial hydrology. In: Mavlyudov, B., (Eds.), Glacier Caves and Glacial Karst in High Mountains and Polar Regions. Institute of geography of the Russian Academy of Sciences, Moscow, pp. 149-177.

Mayer, B., Stoffel, M., Bollschweiler, M., Hübl, J., Rudolf-Miklau, F., 2010. Frequency and spread of debris floods on fans: a dendrogeomorphic case study from a dolomite catchment in the Austrian Alps. Geomorphology 118, 199-206.

Medeu, A.R., 2011. Debris flows in South-Eastern Kazakhstan: Fundamentals of management. Almaty.

Mergili, M., Schneider, J. F., 2011. Regional-scale analysis of lake outburst hazards in the southwestern Pamir, Tajikistan, based on remote sensing and GIS, Nat. Hazards Earth Syst. Sci.,11, 1447-1462. doi:10.5194/nhess-11-1447-2011.

Narama, C., Shimamura, Y., Nakayama, D., Abdrakhmatov, K., 2006. Recent changes of glacier coverage in the western Terskey-Alatoo range, Kyrgyz Republic, using Corona and Landsat. Annals of Glaciology, 43, 223-229.

Narama, C., Duishonakunov, M., Kääb, A., Daiyrov, M., and Abdrakhmatov, K., 2010. The 24 July 2008 outburst flood at the western Zyndan glacier lake and recent regional changes in glacier lakes of the Teskey Ala-Too range, Tien Shan, Kyrgyzstan, Nat. Hazards Earth Syst. Sci., 10, 647-659. doi:10.5194/nhess-10-647-2010.

O’Connor, J.E., Hardison, J.H., III, and Costa, J.E., 2001. Debris flows from failures of Neoglacial-age moraine dams in the Three Sisters and Mount Jefferson Wilderness Areas, Oregon: U.S. Geological Survey Professional Paper 1606, 93 p.

Procter E., Bollschweiler, M., Stoffel, M., Neumann M., 2011. A regional reconstruction of debris-flow activity in the Northern Calcareous Alps, Austria. Geomorphology, 132. 41-50.

Procter, E., Stoffel M, Schneuwly-Bollschweiler M., Neumann M., 2012. Exploring debris-flow history and process dynamics using an integrative approach on a dolomitic cone in western Austria. Earth Surface Processes and Landforms 37, 913-922. 
Reynolds, J.M., Dolecki, A., Portocarrero, C., 1998. The construction of a drainage tunnel as part of glacial lake hazard mitigation at Hualcan, Cordillera Blanca, Peru in Geohaazards in Engineering Geology (ed. By J.G. Maund, M.Eddleston), Geological Society, London, Engineering Geology Special Publ. 15, 41-48.

Richardson, S.D., Reynolds, J.M., 2000. An overview of glacial hazards in the Himalayas. Quaternary International 65, 31-47.

Rickenmann, D., 1999. Empirical relationships of debris flows. Natural Hazards 19, 47-77.

Rinntech, 2011. LINTAB Präzision - Jahrring für Jahrring. http://www.rinntech.com/ content/view/16/47/lang.

Rodriguez-Morata, C., Ballesteros-Cánovas, J.A., Trappmann D., Beniston M., Stoffel M., 2016. Regional reconstruction of flash flood history in the Guadarrama range (Central System, Spain). Science of the Total Environment 550, 406-417.

Ruiz-Villanueva, V., Diez-Herrero, A., Stoffel, M., Bollschweiler, M., Bodoque, J. M., Ballesteros, J.A., 2010. Dendrogeomorphic analysis of flash floods in a small engaged mountain catchment (Central Spain). Geomorphology 118, 383-392.

Schneuwly-Bollschweiler, M., Stoffel, M., 2012. Hydrometeorological triggers of periglacial debris flows in the Zermatt valley (Switzerland) since 1864. J. Geophys. Res. 117, F02033.

Schneuwly-Bollschweiler, M., Corona, C., Stoffel, M., 2013. How to improve dating quality and reduce noise in tree-ring based debris-flow reconstructions. Quat. Geochronol. 18, 110-118.

Schneuwly, D.M., Stoffel, M., Bollschweiler, M., 2009a. Formation and spread of callus tissue and tangential rows of resin ducts in Larix decidua and Picea abies following rockfall impacts. Tree Physiol. 29 (2), 281-289.

Schneuwly, D.M., Stoffel, M., Dorren, L.K.A., Berger, F., 2009b. Three-dimensional analysis of the anatomical growth response of European conifers to mechanical disturbance. Tree Physiol. 29 (10), 1247-1257.

Schwanghart, W., Bernhardt, A., Stolle, A., Hoelzmann, P., Adhikari, B.R., Andermann, C., Tofelde, S., Merchel, S., Rugel, G., Fort, M., Korup, O., 2016. Repeated catastrophic valley infill following medieval earthquakes in the Nepal Himalaya. Science 351, 147-150. doi: $10.1126 /$ science.aac9865.

Šilhán, K. 2014. Chronology of processes in high-gradient channels of medium-high mountains and their influence on alluvial fans properties. Geomorphology 206, 288-298. 
Šilhán, K., Pánek, T., Hradecký, J., Stoffel, M. 2015. Tree-age control on reconstructed debrisflow frequencies: examples from a regional dendrogeomorphic reconstruction in the Crimean Mountains. Earth Surface Processes and Landforms 40, 243-251.

Solomina N.O., Savoskul O.S., Cherkinsky A.E., 1994. Glacier variations, mudflow activity and landscape development in the Aksay Valley (Tian Shan) during the late Holocene. The Holocene $4(1), 25-31$.

Sorg, A., Bolch, T., Stoffel, M., Solomina, O., Beniston, M., 2012. Climate change impacts on glaciers and runoff in Tien Shan (Central Asia). Nature Climate Change, 2(10), 725-731.

Sorg, A., Huss, M., Rohrer M., Stoffel M., 2014. The days of plenty might soon be over in glacierized Central Asian catchments. Environmental Research Letters 9(10). doi: 10.1088/17489326/9/10/104018.

Sorg, A., Kääb, A., Roesch, A., Bigler, C., Stoffel, M., 2015. Contrasting responses of Central Asian rock glaciers to global warming. Scientific Reports, 5, 8228. doi:10.1038/srep08228.

Stoffel, M., Bollschweiler, M., 2008. Tree-ring analysis in natural hazards research - an overview. Natural Hazards and Earth System Sciences 8, 187-202.

Stoffel, M., Huggel, C., 2012. Effects of climate change on mass movements in mountain environments. Progress in Physical Geography 36, 421-439.

Stoffel, M., Liévre, I., Conus, D., Grichting, M., Raetzo, H., Gartner, H.W., Monbaron, M., 2005. 400 years of debris flow activity and triggering weather conditions: Ritigraben, Valais, Switzerland. Arct. Antarct. Alp. Res. 37 (3), 387-395.

Stoffel, M., Conus, D., Grichting, M.A., Lièvre, I., Maître, G., 2008. Unraveling the patterns of late Holocene debris-flow activity on a cone in the Swiss Alps: chronology, environment and implications for the future. Global and Planetary Change 60, 222-234.

Stoffel, M., Bollschweiler, M., Widmer, S., Sorg, A., 2010. Spatio-temporal variability in debrisflow activity: a tree-ring study at Geisstriftbach (Swiss Alps) extending back to AD 1736. Swiss Journal of Geosciences 103, 283-292. 
Stoffel, M., Bollschweiler, M., Beniston, M., 2011. Rainfall characteristics for periglacial debris flows in the Swiss Alps: past incidences - potential future evolutions. Clim. Change 105, 263280.

Stoffel, M., Corona, C., 2014. Dendroecological dating of geomorphic disturbance in tress. Tree Ring Res. 70, 3-20. Stoffel, M., Butler, D.R., Corona, C., 2013. Mass movements and tree rings: a guide to dendrogeomorphic field sampling and dating. Geomorphology 200, 106-120.

Stoffel, M., Tiranti, D., Huggel, C., 2014. Climate change impacts on mass movements - case studies from the European Alps. Science of the Total Environment 493, 1255-1266.

Varnes, D. J., 1978. Slope movement types and processes, in: Landslides, Analysis and Control, edited by: Schuster, R. L. and Krizek, R. J., Washington, Transportation Research Board of the National Academy of Sciences, special report 176, 11-33.

Winchester, V., Passmore, D.G., Harrison, S., Rae, A., Severskiy, I.V., Pimankina, N.V. Dendrogeomorphological and sedimentological analysis of debris flows hazards in the northern Zailiiskiy Alatau, Tien Shan Mountains, Kazakhstan. Vulnerability of Land Systems in Asia 09/2014, 91-116. doi: 10.1002/9781118854945.ch7

Worni, R., Stoffel, M., Huggel, C., Volz, C., Casteller, A., Luckman, B., 2012. Analysis and dynamic modelling of a moraine failure and glacier lake outburst flood at Ventisquero Negro, Patagonian Andes (Argentina), Journal of Hydrology, 134-145.

Worni, R., Huggel, C., Stoffel, M., 2013a. Glacier lakes in the Indian Himalayas - glacier lake inventory, on-site assessment and modeling of critical glacier lakes. Science of the Total Environment 468-469, S71-S84.

Worni, R., Huggel, C., Stoffel, M., 2013b. Glacial lakes in the Indian Himalayas - from an area wide glacial lake inventory to on-site and modelling based risk assessment of critical glacial lakes. Science of the Total Environment 468-469, S71-S84.

Worni, R., Huggel, C., Clague, J. J., Schaub, Y., Stoffel, M., 2014. Coupling glacial lake impact, dam breach, and flood processes: A modeling perspective, Geomorphology, 224, 161-176.

Wu, W., 2015. Recent advances in modeling landslides and debris flows. Springer, Cham. 
Xin X., Yao T., Ye Q., Guo L., Yang W., 2009. Study of the Fluctuations of Glaciers and Lakes 52 around the Ranwu Lake of Southeast Tibetan Plateau using Remote Sensing. Journal of Glaciology and Geocryology, 31(1),19-26. (in Chinese, with English abstract) 


\section{Figure captions}

Fig. 1. (A) The study area is located close to the Kyrgyz capital Bishkek, north of the main divide of the Kyrgyz range, within the Ala-Archa National Park, Aksay valley. (B) View of the cone from west to east and (C) from east to west. (D) Satellite image (QuickBird, 2014) of Aksay cone; distance over main contours is $100 \mathrm{~m}$.

Fig. 2. Changes at the level of the Aksay debris-flow cone: aerial image were taken on (A) 11 Aug 1960; (B) 1 Sept 1971; (C) 8 Aug 1978; and the (D) satellite image (QuickBird, 2014) dates back to 30 Aug 2014.

Fig. 3. Changes in land cover and process relevant parameters at Aksay cone since 1960: (A) number of active and passive debris flow channels as observed in the images. (B) Forest cover for each year, with area in 2014 representing $100 \%$.

Fig. 4. Reconstructed frequency of debris flows on Aksay debris-flow cone. The reconstruction of debris flows was not always possible with the same accuracy, such that we distinguish between events and possible events. For the latter, the number of reacting trees is smaller and the nature of disturbances (and their intensity) less evident. For details see text.

Fig. 5. (A) Maps of Aksay cone with indication of channel activity and spatial patterns of past debris-flow events as recorded in the tree-ring records; as well, forest cover at the time of the event and localization of trees sampled: (B) Debris flow affecting the northern and southern parts of the cone during an event in 1936 (pattern A; for details see text). (C) The debris flows in 1968 affected most parts of the cone and occupied channels in the northern, central, and southern parts of the cone. In some cases debris flows in channels 1, 9, and 10 even reached Ala-Archa River (pattern A). The event of 1968 is known from archives and was triggered by the outburst of an englacial water pocket. (D) During pattern B events, debris flow volumes are smaller and events more limited to some channels, as observed during the debris flow in 1999, which was recorded in channel 8 (central part of the cone) and in channels 3 and 4 (current Aksay channel).

Fig. 6. (A) Past GLOFs have transported very large boulders in the central part of the cone, as illustrated with this example having a diameter of around $13 \mathrm{~m}$. (B) Fresh debris-flow deposits of the event observed on 23 July 2015. 
Fig. 7. (A) The Aksay Glacier complex is formed by two glaciers, Aksay (3) and Uchitel (2), and contains a significant icefall zone (1) and a subglacial lake (4). (B) Frontal view of Aksay icefall and subglacial lake. (C) Glacier movement, based on aerial image (1971). 


\section{Tables}

Table 1. Overview of growth disturbances (GD) and weighted index $\left(\mathrm{W}_{\mathrm{it}}\right)$ values of dated events. Years given in bold are those which were documented in archives, years given in italics were not previously known MAM - March, April, May; JJA - June, July, August. (*) The exact dates of events are based on historical records, the seasonality of unrecorded events is estimated from scars and tangential rows of resin ducts (TRDs) in trees. (**) Observed event.

\begin{tabular}{|c|c|c|c|}
\hline Year & Seasonality/Date (*) & Wit & \#GD \\
\hline 1877 & $J J A$ & 1,1 & 2 \\
\hline 1885 & $J J A$ & 2,3 & 4 \\
\hline 1916 & $J J A$ & 0,9 & 3 \\
\hline 1918 & MAM & 1,2 & 5 \\
\hline 1922 & $J J A$ & 7,5 & 9 \\
\hline 1924 & MAM & 5,3 & 10 \\
\hline 1928 & $J J A$ & 15,5 & 17 \\
\hline $\begin{array}{l}1934 \\
1936\end{array}$ & $\begin{array}{l}J J A \\
J J A\end{array}$ & $\begin{array}{l}4,5 \\
9,1\end{array}$ & $\begin{array}{c}9 \\
11\end{array}$ \\
\hline 1941 & $J J A$ & 1,7 & 6 \\
\hline 1943 & $M A M$ & 3,6 & 9 \\
\hline 1950 & $J J A$ & 11,7 & 15 \\
\hline 1955 & $M A M$ & 0,8 & 5 \\
\hline 1960 & $05^{\text {th }}$ July & 12,7 & 19 \\
\hline 1961 & $29^{\text {th }}$ July & 1,2 & 6 \\
\hline 1965 & $21^{\text {st }}$ August & 2,0 & 8 \\
\hline 1966 & $18^{\text {th }}$. June & 1,4 & 7 \\
\hline 1968 & $24^{\text {th }}$ July & 2,6 & 9 \\
\hline 1969 & $2^{\text {th }}$ July & 10,6 & 14 \\
\hline 1970 & $18^{\text {th }}$ July and $2^{\text {nd }}$ August & 7,7 & 14 \\
\hline 1973 & $J J A$ & 1 & 6 \\
\hline 1975 & $M A M$ & 1,5 & 6 \\
\hline 1977 & $M A M$ & 1,2 & 5 \\
\hline 1980 & $18^{\text {th }}$ July and August & 22,2 & 25 \\
\hline 1993 & $M A M$ & 1,4 & 6 \\
\hline 1999 & June & 2,1 & 7 \\
\hline $2015(* *)$ & $23^{\text {rd July }}$ & - & - \\
\hline
\end{tabular}


Table 2. Debris-flow channels and periods of activity

\begin{tabular}{cccc}
\hline Channel & First event & $\begin{array}{c}\text { Last } \\
\text { Event }\end{array}$ & $\begin{array}{c}\text { Number } \\
\text { of event }\end{array}$ \\
\hline 1 & 1922 & 1970 & 15 \\
2 & 1928 & 1980 & 13 \\
3 & 1924 & 2015 & 18 \\
4 & 1924 & 2015 & 13 \\
5 & 1877 & 1977 & 10 \\
6 & 1877 & 1970 & 13 \\
7 & 1885 & 1977 & 10 \\
8 & 1918 & 2015 & 7 \\
9 & 1960 & 1969 & 3 \\
10 & 1960 & 1969 & 5 \\
11 & 1960 & 1969 & 4 \\
\hline
\end{tabular}


Table 3. Historical events on Aksay debris flow cone (Erochin and Dikih, 2003)

\begin{tabular}{|c|c|c|c|c|}
\hline Valley & $\begin{array}{l}\text { Reasons of } \\
\text { debris flow }\end{array}$ & Date of outburst & $\begin{array}{c}\text { Initial outburst } \\
\text { discharge, } \mathrm{m}^{3} / \mathrm{sec}\end{array}$ & $\begin{array}{c}\text { Debris-flow } \\
\text { discharge, } \mathrm{m}^{3} / \mathrm{sec}\end{array}$ \\
\hline \multirow{9}{*}{ Aksay } & \multirow{9}{*}{$\begin{array}{c}\text { Outburst of } \\
\text { Aksay } \\
\text { englacial } \\
\text { water pocket }\end{array}$} & 08.07 .1960 & $5-10$ & - \\
\hline & & 07.1961 & $5-10$ & - \\
\hline & & 21.07 .1965 & $5-10$ & - \\
\hline & & $18.06 .1966^{*}$ & 5,5 & 70 \\
\hline & & 10.08 .1968 & 7,5 & 900 \\
\hline & & 25.07 .1969 & 5 & 800 \\
\hline & & $18.07 ; 2.08 .1970$ & $5-10$ & \\
\hline & & $18.07 .1980 *$ & 3,3 & 40 \\
\hline & & $3.08 .1980 *$ & 3,6 & 45 \\
\hline $\begin{array}{l}\text { Sharkyratma } \\
\text { (side valley) }\end{array}$ & rainfall & 1999 & - & 70 \\
\hline Aksay & $\begin{array}{l}\text { Intensive } \\
\text { melting }\end{array}$ & 23.07 .2015 & & $90-150$ \\
\hline
\end{tabular}

*estimation of discharge in 1980 was visually and measured in the lower part of the cone, near the confluence with the Ala-Archa river; in 1966, discharge estimates was visually done by alpinists during the event and again in the lower parts of the cone 


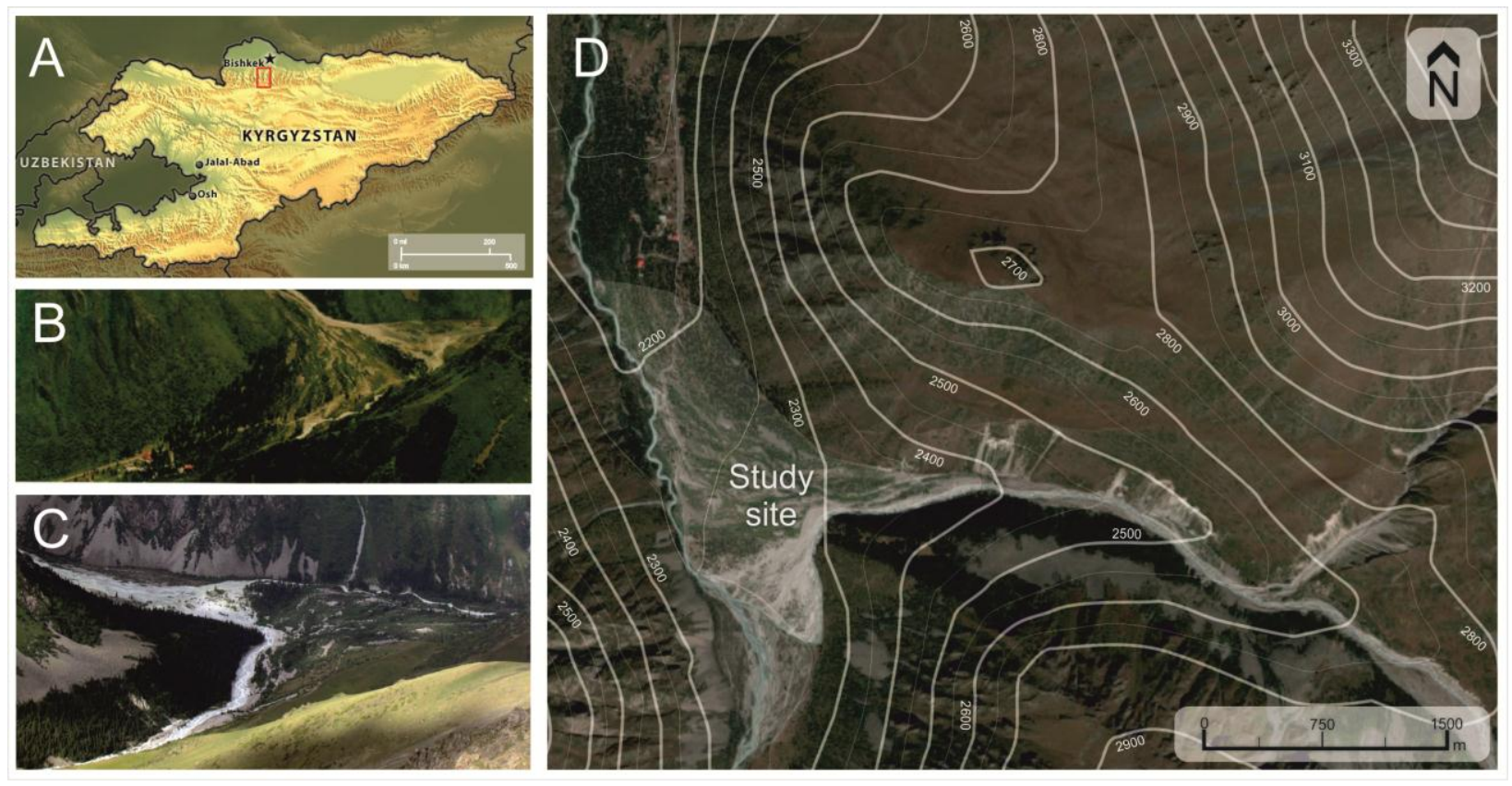




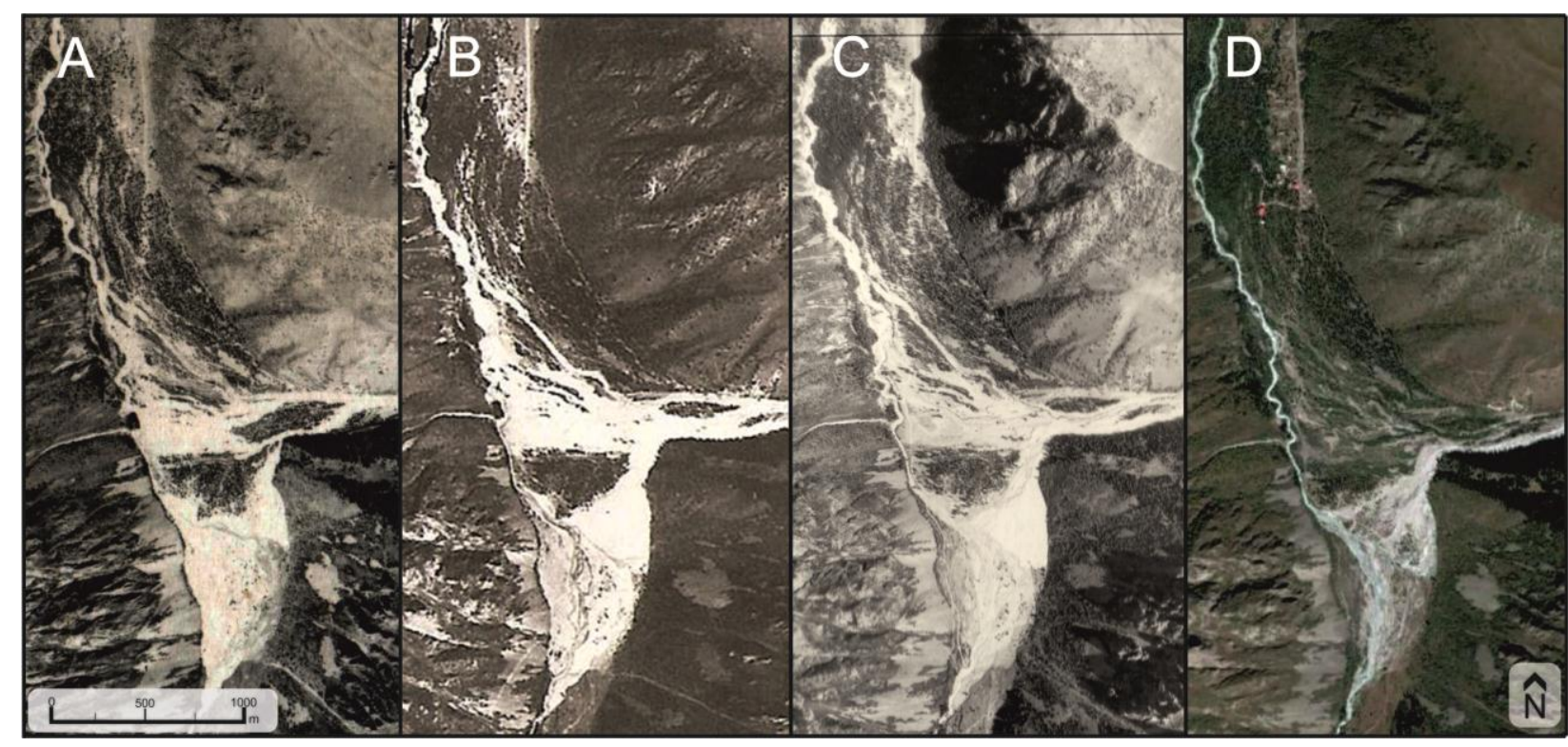




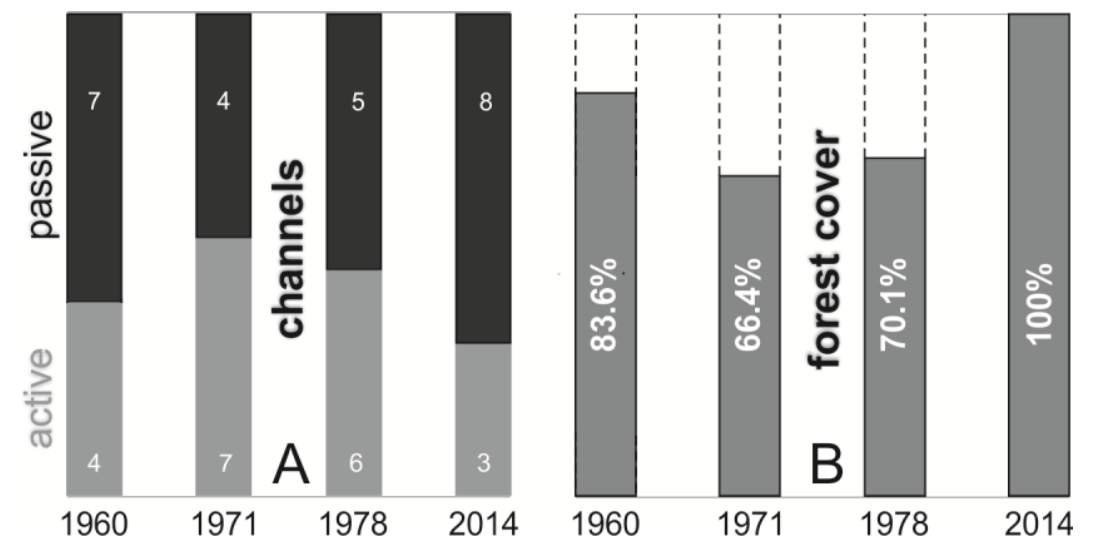




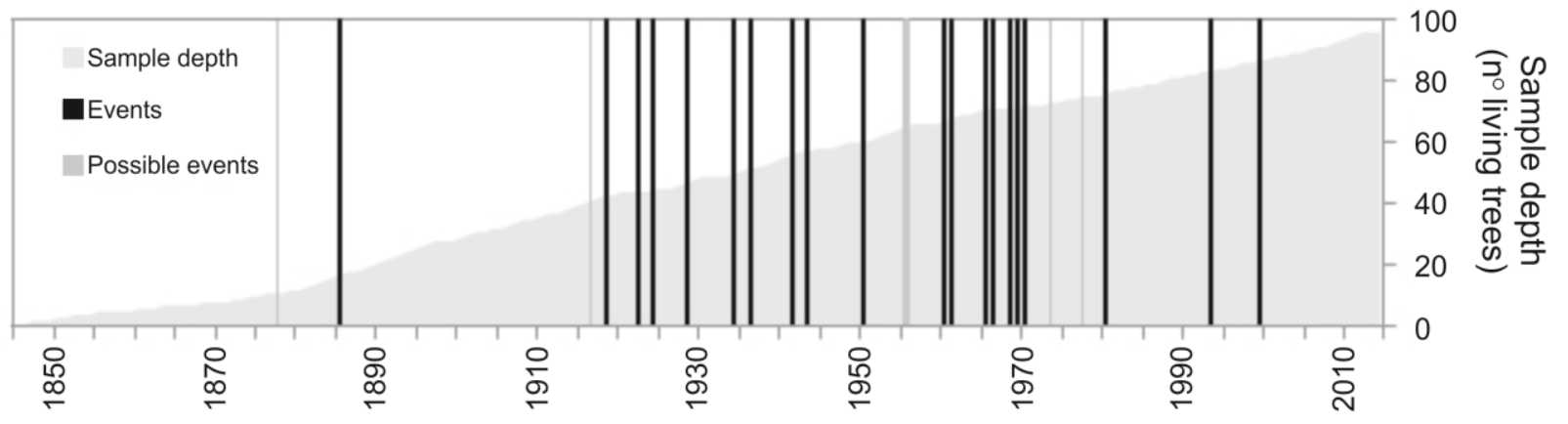




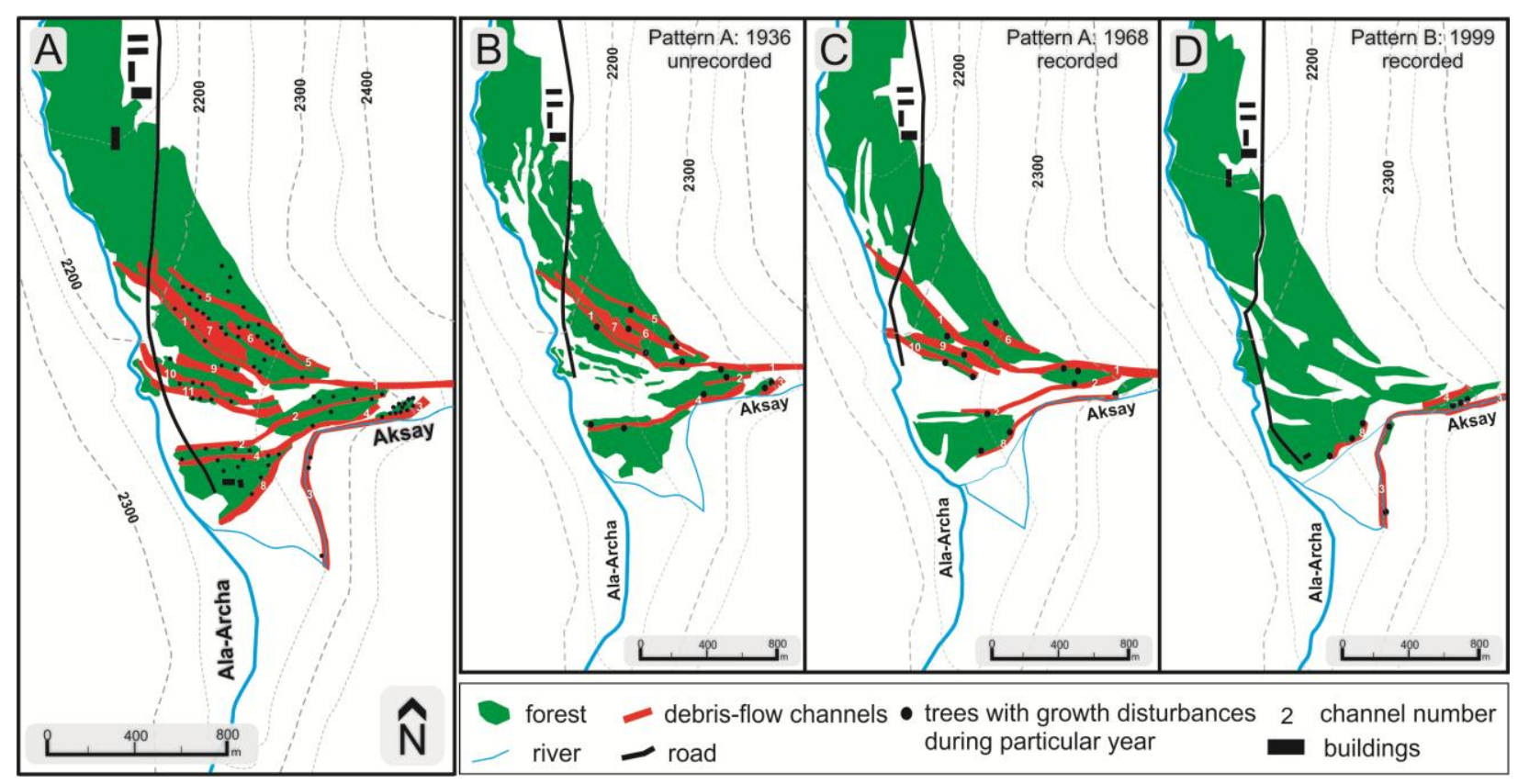




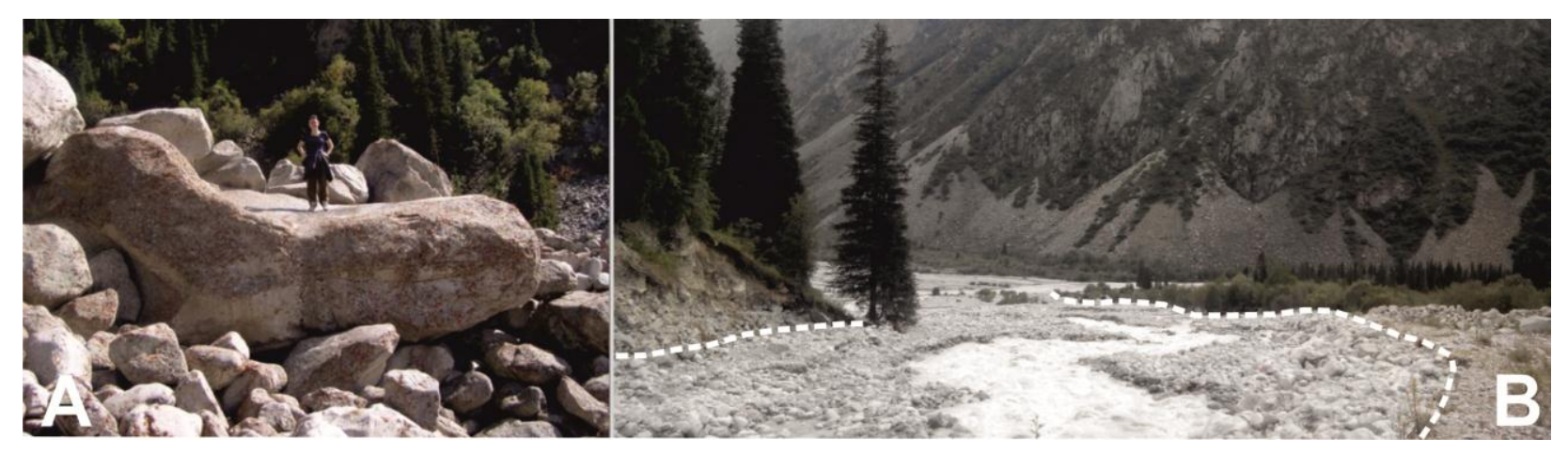




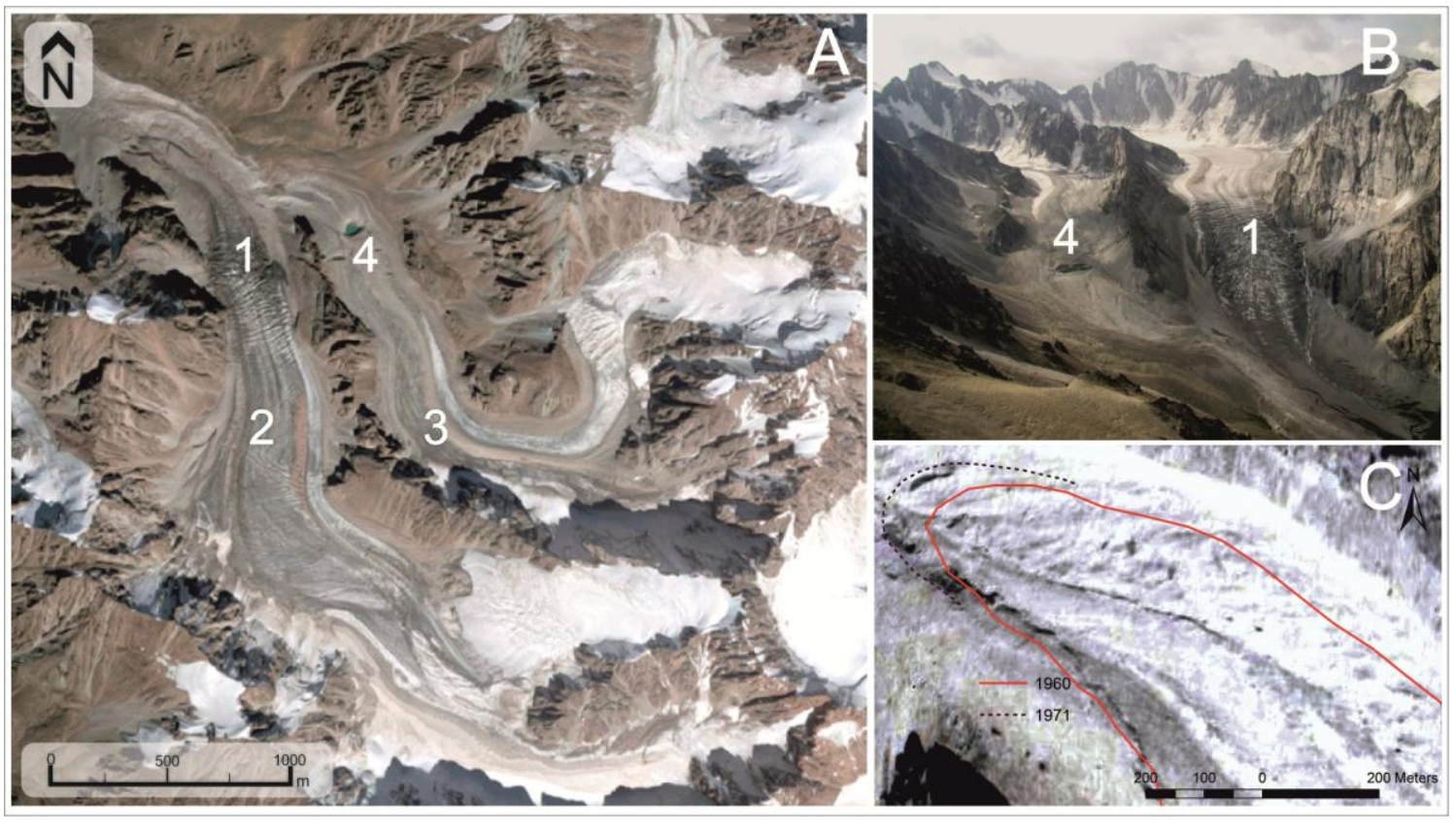

